Sains Malaysiana 47(6)(2018): 1227-1234

http://dx.doi.org/10.17576/jsm-2018-4706-18

\title{
Najis (Tinja) Manusia daripada Perspektif Sains dan Islam serta Amalan Pemakanan Sunnah
}

(Human Stool from Science and Islam Perspective and Sunnah Dietary Practices)

\begin{abstract}
MOHD IZHAR ARIFF MOHD KASHIM*, NUR ASMADAYANA HASIM, RIZAFIZAH OTHAMAN, ROZIDA KHALID, MUHAMMAD AdiB SAMSUDin, MOHAMMAD ZAINI YAHAYA, ZAHARA ABDUl MANAF, LATIFAH AMIN \& DiANI MARDIANA MAT ZIN
\end{abstract}

\section{ABSTRAK}

Islam merupakan satu agama yang menitikberatkan kesihatan manusia termasuklah sistem pencernaan manusia. Najis (tinja) manusia yang dibincangkan dalam kajian ini merupakan hasil buangan manusia yang menjadi salah satu kaedah untuk melihat sudut kesihatan manusia. Objektif penyelidikan ini ialah untuk mengkaji fizikokimia dan ciri-ciri najis serta kegunaannya daripada perspektif sains dan sudut pandangan Islam terutamanya mengenai diet yang diamalkan oleh Rasulullah SAW. Kajian ini dijalankan dengan menggunakan ulasan literatur secara deskriptif. Kajian mendapati bahawa sistem pencernaan merupakan satu sistem yang rumit. Tinja terdiri daripada $75 \%$ air dan $25 \%$ bahan pepejal serta ciri-ciri tinja seperti bentuk, warna dan bau memberi kesan kepada kesihatan manusia. Daripada sudut Islam warna, bau dan rasa tinja merupakan perkara asas yang dititikberatkan semasa proses pembersihan najis terutamanya bagi memulakan sesuatu ibadah. Selain itu, diet, senaman, umur dan jantina merupakan faktor-faktor yang membezakan jenis tinja bagi setiap individu. Malah, kajian ini juga merungkai beberapa alternatif yang kini diguna pakai bagi mengurus najis-najis manusia dalam menjamin kesihatan dan pemeliharaan alam sekitar. Kajian ini kemudiannya mengupas diet makanan-makanan sunnah yang terdapat di dalam Al-Quran dan hadis yang terbukti kaya dengan serat dan sihat untuk manusia terutamanya bagi sistem pencernaan manusia. Oleh itu, najis (tinja) manusia daripada sudut sains mampu menggambarkan kesihatan seseorang dan amalan diet makanan-makanan sunnah sangat baik dalam memelihara sistem pencernaan manusia.

Kata kunci: Al-Quran dan hadis; kegunaan najis; kesihatan manusia; makanan sunnah; najis (tinja) manusia

ABSTRACT

Islam is a religion that emphasizes human health including the human digestive system. The human stool (stool) discussed in this study is a human waste which is one of the way to look at human health. The objectives of this research were to study the physiochemical and characteristics of stool and its usefulness from the perspective of science while the diet used by Rasulullah SAW is been described from the Islam perspective. The research was conducted using descriptive literature review. It was found that the digestive system is a complicated system. The stools is made up of 75\% of water and $25 \%$ of solid materials and the characteristics of stools such as form, color and odor can affect human health. From the Islam perspectives, color, odor and taste are the fundamental factors need to be emphasized during the process of stool's cleansing especially before religious rituals begin. In addition, diet, exercise, age and gender are the factors that differentiate the type of human stool. In fact, this study also stated some of the alternatives that are currently used to manage stools in maintaining health and environmental protection. This study then examined the diet of sunnah's foods called in the Qur'an and the hadith which is proven to be rich in fiber and nutritious especially for the human digestive system. Therefore, the stools from the perspective of science are capable in describing human health and the diet of sunnah's food is very good for the human digestive system.

Keywords: Characteristic of stool; human health; human stool (stool); Qur'an and Hadith; sunnah's food

\section{PENGENALAN}

Islam sangat menekankan nyawa dan kesihatan manusia (Ariff 2013). Hal ini dapat bertepatan dengan sabda Nabi SAW yang bermaksud: "Janganlah kamu memudaratkan diri kamu dan orang lain" (Ibn Majah 1999: Hasan Sahih). Makanan dan minuman adalah sumber tenaga dan keperluan fisiologi yang perlu dipenuhi untuk kelangsungan kehidupan seharian manusia. Selain itu, Islam juga turut menjadikan pengambilan makanan yang halal dan baik bagi tujuan pengabdian diri kepada Allah SWT di samping memperoleh ganjaran syurga di akhirat kelak (Ariff 2013). Walau bagaimanapun, tidak semua makanan yang dimakan dapat diserap ke saluran darah dan sel badan (Choong et al. 2017). Hanya sebahagian kecil daripada makanan yang terdiri daripada molekul kecil yang mampu meresap ke dalam sel badan atau saluran darah seperti gula, mineral dan vitamin. Makanan yang dimakan kebanyakannya terdiri daripada molekul besar 
dan tidak serap seperti kanji, protein dan lemak yang perlu dipecahkan oleh badan kepada bahan makanan kecil dan boleh serap. Proses memecahkan makanan kepada molekul boleh larut dan boleh serap dikenali sebagai pencernaan (Choong et al. 2017). Rajah 1 menunjukkan organ manusia yang terlibat dalam proses pencernaan. Pencernaan bermula daripada mulut apabila makanan dikunyah (pencernaan fizikal) dan saliva membantu untuk melembab dan menghancurkan makanan. Makanan yang telah lembap akan digumpal dalam bentuk bolus yang kemudiannya ditelan melalui esofagus ke perut. Perut menghasilkan bahan-bahan kimia yang dipanggil enzim yang berfungsi untuk menyambung penghancuran makanan melalui pencernaan kimia (Caroline \& Marry 2008). Tindakan otot-otot perut menyebabkan makanan di dalam perut hancur. Isi perut, hempedu daripada hati serta jus daripada pankreas juga memasuki usus kecil. Bahan-bahan kimia ini menghancurkan makanan ke bentuk cecair. Kapilari di dalam usus kecil menyerap nutrisi dan mengagihkan mereka ke dalam saluran darah untuk menyuburkan setiap sel di dalam badan. Proses pencernaan dan penyerapan makanan yang unik lengkap di dalam usus kecil. Air dan sisa daripada pencernaan memasuki usus besar. Oleh sebab campuran ini melalui tiub, banyak air diserap semula ke dalam badan (Caroline \& Marry 2008)

Apabila sisa sampai ke bahagian bawah usus, sisa tersebut membentuk menjadi najis. Najis disimpan dalam rektum manakala air yang terdapat pada rektum akan diserap. Proses mengeluarkan najis daripada tubuh adalah rumit dan melibatkan sistem pencernaan, pergerakan otot (muscular) dan sistem saraf (Caroline \& Marry 2008). Apabila rektum dipenuhi dengan najis, saraf akan menghantar isyarat kepada otak untuk memaklumkan bahawa tiba masanya untuk pergerakan usus/isi perut (bowel movement). Peristalsis menyebabkan najis bergerak; otot dalam dan luar membolehkan liang dubur terbuka dan najis dikeluarkan daripada badan (Caroline \& Marry 2008).

\section{DEFINISI DAN CIRI-CIRI NAJIS (TINJA) MANUSIA}

Najis (Tinja) manusia ialah sesuatu benda/perkara yang dipandang keji dalam Islam kerana dianggap sebagai bahan buangan manusia. Ini kerana, tinja termasuk dalam kategori najis yang bermaksud kotoran yang menyebabkan sembahyang dan tawaf yang didirikan tidak sah (AlSharbini 1994). Seseorang yang terkena tinja hendaklah menyucikannya terlebih dahulu sebelum melakukan ibadat seperti solat, tawaf dan menyentuh al-Quran. Tinja merupakan produk sisa pepejal badan hasil daripada pencernaan yang terdiri daripada produk akhir metabolisma dan makanan-makanan yang terhadam. Sebanyak $75 \%$ daripada tinja adalah air manakala $25 \%$ daripada tinja terdiri daripada bahan pepejal. Menerusi pecahan pepejal, $84 \%$ hingga 93\% adalah bahan organik (Bai \& Wang 2011). Pecahan pepejal organik dipecahkan kepada 2-25\% protein atau bahan nitrogen (dengan tambahan $50 \%$ biojisim bakteria dalam protein) (Volk \& Rummel 1987), $25 \%$ karbohidrat atau bahan bukan nitrogen tumbuhan tidak hadam (Volk \& Rummel 1987), 2-15\% lemak tidak hadam (Wierdsma et al. 2011) dan 25-54\% biojisim bakteria (Guyton \& Hall 2000). Kolon manusia mempunyai populasi bakteria dalam badan paling besar (lebih 1011 organisma per gram daripada berat basah) dan majoriti organisma ini adalah anaerob dan $25 \%$ adalah daripada spesies Bacteroid iaitu predominan anaerob dalam usus, hempedu perintang, tidak menghasilkan sfora, gram-negatif dan diperoleh daripada najis manusia. Organisma ini terdiri daripada peranan mereka sebagai organisma komensal (bakteria baik) dan penglibatan mereka dalam penyakit manusia (bakteria jahat) (Hannah 2007). pH tinja adalah neutral dengan nilai median $\mathrm{pH} 6.6$ dan pada julat min nilai $\mathrm{pH}$ pada

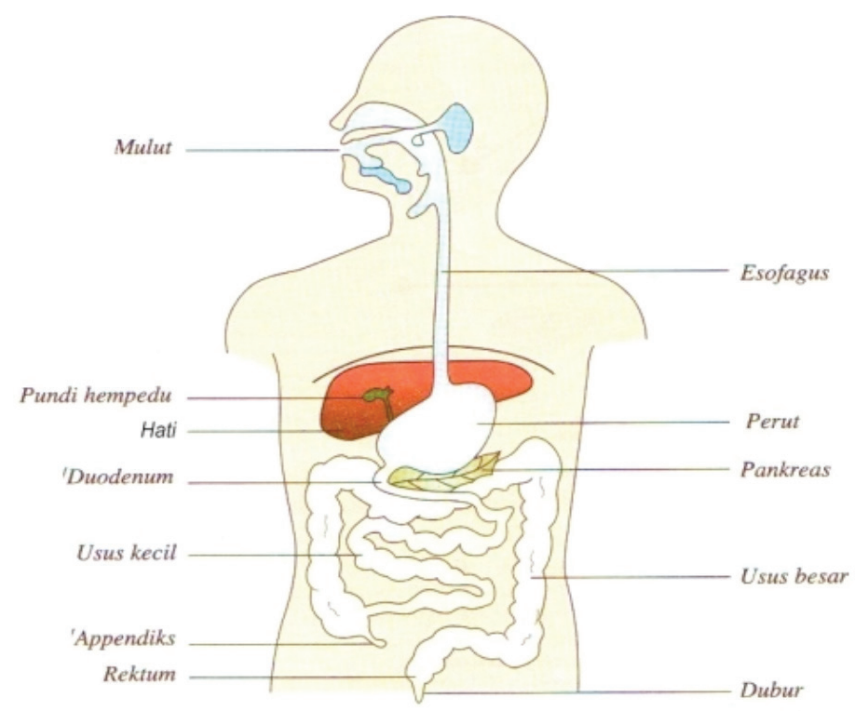

RAJAH 1. Sistem pencernaan manusia 
5.3-7.5 ( $n=23)$. pH tinja tidak hanya berbeza antara populasi yang berbeza tetapi juga dibuktikan bahawa berbeza antara setiap individu yang mengambil diet yang sama pada masa yang sama (Silvester et al. 1997).

\section{WARNA NAJIS (TINJA) MANUSIA}

Keputusan daripada kajian yang telah dijalankan oleh para saintis mendapati bahawa tinja mempunyai beberapa warna. Setiap warna yang telah dikenal pasti memberi makna tersendiri terhadap kesihatan manusia. Antara warna-warna tinja dan penerangan yang telah dikenal pasti adalah seperti yang dilampirkan dalam Jadual 1.

\section{BENTUK NAJIS (TINJA) MANUSIA}

Perlu diingatkan juga bahawa bentuk dan sifat tinja memainkan peranan penting dalam mengenal pasti kesihatan dalaman seseorang. Terdapat beberapa jenis atau sifat tinja yang telah dikenal pasti. Antaranya adalah seperti berikut:

Tinja yang bersifat lembut dan terbentuk dengan baik. Kebiasaannya tinja seperti ini bersifat normal dan sihat kerana ia telah terbentuk dengan baik mengikut keluasan lubang dubur seseorang (Corsetti et al. 2009); Manakala tinja yang keras, kering (sembelit) terjadi apabila rektum tidak dikosongkan seperti yang diperlukan dan lebihan cecair telah diserap semula terlalu banyak (Corsetti et al. 2009; Edward 2007). Keadaan ini biasanya berlaku apabila seseorang itu mengelak untuk mengosongkan rektum semasa mendapat rangsangan untuk membuat air besar. Sembelit juga merupakan kesan daripada tidak mengambil bendalir dengan cukup atau tidak cukup senaman untuk merangsang proses peristalsis selain daripada akibat daripada beberapa jenis perubatan atau kesan selepas pembendahan (Corsetti et al. 2009; Edward 2007).

Secara umumnya, tinja mempunyai bentuk yang sama seperti dalaman usus iaitu bulat, bujur atau silinder
(Edward 2007). Satu skala yang sering digunakan dalam klinikal dan uji kaji iaitu Skala Najis Bristol (Bristol Stool Scale) (Corsetti et al. 2009) seperti yang ditunjukkan dalam Jadual 2. Perbezaan bentuk dan tekstur tinja berlaku antara individu, umur, jantina dan bergantung kepada diet dan kesihatan individu (Davies et al. 1986; Heaton et al. 1992).

Diarea/ cirit-birit merupakan pembuangan tinja yang berair dan tidak terbentuk. Cirit-birit yang berterusan menunjukkan iritasi kronik pada kolon, jangkitan usus, keracunan makanan atau jangkitan parasit. Keadaan emosi seseorang juga memberi kesan kepada struktur tinja (Edward 2007).

Berbeza dengan termaim paksi yang merujuk kepada najis yang sangat keras atau kering yang tidak boleh dikeluarkan. Hal ini kebiasaanya merupakan hasil daripada masalah usus yang kronik, keadaan badan yang tidak dapat bergerak, lumpuh atau penyahidratan (Edward 2007). Individu yang dirawat dengan arang kerana keracunan juga akan menyebabkan impaksi dan mempunyai tinja berwarna hitam (Edward 2007). Antara simptom impaksi tinja termasuklah abdomen yang sangat tidak selesa dan rasa tertekan. Individu tersebut merasa terdesak untuk membuang tetapi tidak mampu melakukannya atau tidak mampu mengosongkan usus sepenuhnya (Edward 2007).

\section{CIRI-CIRI LAIN NAJIS (TINJA)}

Selain itu, terdapat juga kajian menunjukkan bahawa antara tanda mengenali tinja ialah menerusi baunya yang busuk. al-Nawawi RH (t.th) menukilkan daripada Ibn Munzir bahawa tiga ciri mengenali najis (termasuk tinja) iaitu melalui deria bau, warna dan rasa. Atas asas tersebut juga, kajian membuktikan bahawa segala jenis perubatan, makanan berperisa kuat atau kehadiran mikroorganisma yang asing juga mengubah bau tinja. Contohnya protein daging yang mempunyai banyak asid amino, methionine yang mengandungi sulfur yang menjadi petanda sebatian bau (Magee et al. 2000). Gas yang dikeluarkan boleh berbau sangat kuat dan dikenali

JADUAL 1. Warna tinja dan penerangan

\begin{tabular}{ll}
\hline Warna Tinja & \multicolumn{1}{c}{ Penerangan } \\
\hline Coklat kekuningan & $\begin{array}{l}\text { Warna coklat kekuningan ini bergantung kepada kehadiran hempedu. Perubahan dalam warna berkait } \\
\text { dengan perubahan dalam penggunaan gastro usus atau kandungan najis }\end{array}$ \\
Kelabu (Tanah liat) & $\begin{array}{l}\text { Kebiasaannya menunjukkan hempedu hilang. Kebiasaan tinja berwarna ini menunjukkan terdapat tanda } \\
\text { penyakit pundi hempedu yang perlu diambil perhatian serta rawatan daripada pakar perubatan }\end{array}$ \\
& $\begin{array}{l}\text { Kebiasaanya menunjukkan kehadiran darah yang tercerna yang dipanggil melena. Ia disebabkan daripada } \\
\text { pendarahan (hemorrhage) yang banyak dalam saluran gastro usus atau darah yang ditelan daripada mulut } \\
\text { dan hidung atau luka/penyakit tekak }\end{array}$ \\
& $\begin{array}{l}\text { Terjadi samada dalam atau luar tinja menunjukkan pendarahan rektum atau dubur yang selalunya daripada } \\
\text { hemoroid/buasir. Ia juga antara tanda-tanda penyakit kenser usus, namun begitu ia bergantung kepada } \\
\text { pemeriksaan terperinci oleh pakar perubatan } \\
\text { Merah terang }\end{array}$ \\
& $\begin{array}{l}\text { Menunjukkan kehadiran mikroorganisma yang tidak normal berkemungkinan daripada jangkitan. } \\
\text { berserat dan sebagainya }\end{array}$ \\
\hline Kuning/ Hijau &
\end{tabular}


JADUAL 2. Skala najis bristol

\begin{tabular}{|c|c|c|c|}
\hline Jenis & Bentuk & Huraian & Kelas \\
\hline Jenis 1 & & $\begin{array}{l}\text { Ketulan keras yang berasingan seperti } \\
\text { kekacang (sukar untuk keluar) }\end{array}$ & Sangat sembelit \\
\hline Jenis 2 & & Berbentuk seperti sosej tetapi berketul & Agak sembelit \\
\hline Jenis 3 & & $\begin{array}{l}\text { Seperti sosej tetapi ada rekahan pada } \\
\text { permukaan }\end{array}$ & Normal \\
\hline Jenis 4 & & Seperti sosej atau ular, licin dan lembut & Normal \\
\hline Jenis 5 & & $\begin{array}{l}\text { Bergumpal-gumpal, lembut dengan } \\
\text { potongan hujungnya jelas }\end{array}$ & Tanda diarea \\
\hline Jenis 6 & & $\begin{array}{l}\text { Dipenuhi dengan cebisan yang hujungnya } \\
\text { bergerigis, najis yang lembik }\end{array}$ & Diarea/Cirit-birit \\
\hline Jenis 7 & & Sangat cair, tiada pepejal & $\begin{array}{l}\text { Diarea/ Cirit-birit } \\
\text { kronik }\end{array}$ \\
\hline
\end{tabular}

Sumber: Corsetti et al. 2009

buang angin (flatus). Hidrogen sulfida merupakan sebatian meruap yang paling biasa ada pada tinja (Magee et al.2000). Ketumpatan tinja merupakan berat kepekatan bahan sisa dengan air. Kebiasaanya, tinja adalah cukup berat untuk tenggelam di dalam air. Tinja yang timbul adalah kurang tumpat berkemungkinan terdiri daripada lemak yang tidak cerna, terutamanya jika ia kelihatan seperti lemak atau berminyak (Edward 2007). Steatorea merupakan terma yang digunakan untuk mengenal pasti tinja yang tinggi kandungan lemak. Jika tinja timbul ia juga berkemungkinan kerana penyakit pundi hempedu atau fibrosis sista (Edward 2007).

Kehadiran nanah atau lendir di dalam najis menunjukkan radang atau jangkitan di mana-mana bahagian pada sistem pencernaan (Edward 2007). Kehadiran bahan makan yang tidak cerna berkemungkinan adalah akibat sistem pencernaan yang kurang berfungsi (malfunction). Darah merah terang (melena) pula menandakan jenis-jenis pendarahan (Edward 2007). Ringkasan ciri-ciri najis boleh dilihat pada Jadual 3.

\section{KEGUNAAN NAJIS (TINJA)}

Kehadiran bakteria koliform, koliform tahi, E. coli O157:H7 dan streptokokus tahi adalah salah satu masalah yang ketara daripada segi kesihatan awam dalam ekosistem marin dunia (Ismet \& Cumhur 2014).
Walaupun tinja merupakan bahan buangan badan, namun pada zaman moden ini pelbagai kaedah digunakan bagi memastikan najis diurus dengan baik dan efisyen (Rose et al. 2015). Pelupusan tinja manusia dan binatang yang selamat adalah penting untuk kesihatan dan kebajikan terutamanya bagi negara berpendapatan rendah di samping mencegah pencemaran alam sekitar (Rose et al. 2015). Namun bagi tinja yang telah dirawat daripada patogen boleh digunakan dengan selamat dalam pertanian sebagai baja (WHO 2010).

Penghasilan biogas daripada najis(tinja) kumbahan yang dirawat dengan proses pencernaan anaerobik mampu bernilai 9.5 billion dolar (Dnews 2015). Metana daripada tinja merupakan gas rumah hijau. Jika dilepaskan ke atmosfera ia lebih teruk untuk alam sekitar berbanding perlepasan karbon dioksida. Oleh itu langkah untuk mengurangkan pengeluaran gas ini ialah dengan menpertimbangkan tinja sebagai sumber tenaga boleh diperbaharui seperti biogas (Frederika 2014).

Tinja juga digunakan dalam bakterioterapi najis atau dikenali sebagai transplan najis. Transplan najis adalah satu proses transplantasi bakteria najis daripada individu yang sihat kepada penerima yang menghidapi sesetengah penyakit seperti sindrom iritasiusus (Rowan 2012). Kajian terkini menunjukkan kaedah ini mungkin bernilai untuk mewujudkan semula kultur usus normal 
JADUAL 3. Ringkasan ciri-ciri najis manusia

\begin{tabular}{|c|c|c|c|}
\hline Perkara & Normal & Abnormal & Penyebab abnormal \\
\hline Warna & $\begin{array}{l}\text { Bayi: Kuning } \\
\text { Dewasa: Coklat }\end{array}$ & $\begin{array}{l}\text { Putih atau kelabu } \\
\text { Hitam atau tar (melena) } \\
\text { Merah } \\
\text { Pucat atau berminyak }\end{array}$ & $\begin{array}{l}\text { Ketiadaan hempedu } \\
\text { Pengingesan zat besi atau pendarahan GI } \\
\text { Pendarahan GI, buasir, pengingesan bit } \\
\text { Malserapan lemak }\end{array}$ \\
\hline $\mathrm{Bau}$ & $\begin{array}{l}\text { Bau yang tidak menyenangkan: } \\
\text { mungkin kesan daripada } \\
\text { sesetengah makanan }\end{array}$ & & Darah dalam najis atau jangkitan \\
\hline Kekonsistenan & Lembut, terbentuk & $\begin{array}{l}\text { Cecair } \\
\text { Keras }\end{array}$ & $\begin{array}{l}\text { Cirit-birit, kurang penyerapan } \\
\text { Sembelit }\end{array}$ \\
\hline \multirow[t]{2}{*}{ Kekerapan } & $\begin{array}{l}\text { Bayi: 4-6 kali sehari (susu badan) } \\
\text { atau 1-3 kali sehari (susu botol) }\end{array}$ & $\begin{array}{l}\text { Bayi: lebih daripada } 6 \text { kali sehari atau } \\
\text { kurang daripada sekali pada setia } 1-2 \text { hari }\end{array}$ & Hipermotiliti atau hipomotiliti \\
\hline & $\begin{array}{l}\text { Dewasa: } 2 \text { kali sehari ke } 3 \text { kali } \\
\text { seminggu }\end{array}$ & $\begin{array}{l}\text { Dewasa: lebih daripada } 3 \text { kali sehari atau } \\
\text { kurang sari pada sekali seminggu }\end{array}$ & \\
\hline Bentuk & Menyerupai diameter rektum & Sempit, berbentukpensil & Halangan, peningkatan peristalsis \\
\hline \multirow[t]{3}{*}{ Konstituen } & $\begin{array}{l}\text { Makanan yang tidak hadam, } \\
\text { bakteria mati, lemak, pigmen } \\
\text { hempedu,lapisanlendirselusus, air }\end{array}$ & Darah, nanah, benda asing, lendir, cacing & $\begin{array}{l}\text { Pendarahan dalaman, jangkitan, tertelan } \\
\text { objek, iritasi, keradangan, serangan } \\
\text { parasit }\end{array}$ \\
\hline & & Najis berminyak & $\begin{array}{l}\text { Sindrom malserapan, tidak balas } \\
\text { pembedahan usus, enteritis, penyakit } \\
\text { pankreas }\end{array}$ \\
\hline & & Lendir & $\begin{array}{l}\text { Iritasi usus, keradangan, jangkitan atau } \\
\text { cedera }\end{array}$ \\
\hline
\end{tabular}

Sumber: Patricia et al. 2015

yang telah dimusnahkan dengan penggunaan antibiotik atau rawatan perubatan lain (Rowan 2012).

\section{MAKANAN SUNNAH YANG TERBUKTI BAIK UNTUK PENCERNAAN \& PERUT MANUSIA}

Diet dan kesihatan merupakan faktor utama dalam memastikan kesihatan penghadaman terjaga. Serat diet memberi kesan kepada peningkatan kelembutan pada tekstur tinja (Davies et al. 1986). Terdapat banyak hadis yang menjelaskan tentang pemakanan Nabi Muhammad S.A.W. Kebiasaannya, makanan yang biasa dimakan oleh baginda mempunyai kandungan serat yang baik untuk penghadaman. Serat diet mengurangkan risiko masalah usus seperti sembelit, buasir dan inflamasi usus (Kantor et al. 2001). Saranan pengambilan buah-buahan dan sayursayuran sehari adalah 5 hidangan iaitu bersamaan dengan 400 gram yang terdiri daripada pelbagai jenis dan warna (NCCFN 2010). Di dalam al-Quran dan hadis banyak disebut tentang saranan memakan buah-buahan seperti kurma, zaitun, tin dan delima yang sememangnya kaya dengan serat dan pelbagai sumber mineral (Faszly et al. 2015). Antara beberapa makanan sunnah yang menjadi penawar dalam menjaga kesihatan perut dan pencernaan manusia ialah seperti berikut:

Buah zaitun Buah zaitun atau nama saintifik bagi buah zaitun ialah Olea europaea L. (Süntar et al. 2010). Buah zaitun disebut beberapa kali di dalam al-Quran dan hadis.
Di dalam hadis riwayat daripada ${ }^{\mathrm{C}} \mathrm{Uqbah}$ bin ${ }^{\mathrm{c}} \mathrm{Amir}$ bahawa Rasulullah S.A.W. bersabda yang bermaksud:

"Hendaklah kamu menggunakan pohon yang berkat ini iaitu minyak zaitun. Berubatlah dengannya kerana sesungguhnya ia adalah penyembuh kepada penyakit buasir" (al-Tabarani 1994).

Buah zaitun dan daunnya didapati berfungsi sebagai anti keradangan dan aktiviti antinociceptive (Süntar et al. 2010). Malah terdapat kajian yang menunjukkan bahawa $n$-hexane dan ethanolik yang diekstrak daripada buah zaitun boleh dijadikan kegunaan sebagai ubatan atau rawatan tradisional atau alternatif bagi penyakit buasir dan sakit sendi selain mengandungi bahan fenolik yang tinggi yang berfungsi sebagai anti oksida dalam badan (Süntar et al. 2010).

Buah Delima Buah delima (Punica granatum) tergolong dalam keluarga Punicaceae. Jenis pokok yang rendah dan renek dipercayai berasal dari Afghanistan dan Iran (Panth et al. 2017). Khasiat delima sangat banyak sehinggakan Ali bin Abi Talib r.a. pernah berkata yang bermaksud:

"Makanlah buah delima bersama pembahaginya, sesungguhnya ianya adalah pencuci perut” (Ahmad Ibn Hanbal 2001).

Hal ini terbukti dengan kajian oleh para saintis pada 1985, yang menyatakan buah delima berserta kulitnya terbukti mampu mengubati cirit birit dan ulser 
(Arseculeratne et al. 1985; Ramirez et al. 1988). Selain itu, menurut Paudel et al. (2017), kanser yang boleh dicegah menggunakan buah delima dan hasil-hasil daripadanya seperti kanser payu dara, kanser prostat, leukimia dan kanser pundi kencing. Malah, berdasarkan kaedah perubatan cina, ekstrak daripada buah delima (kulit delima, akar, jus dan kulit) yang dikeringkan digunakan untuk merawat pelbagai penyakit kronik (Lei et al. 2007).

Kurma Saranan pengambilan buah-buahan dan sayursayuran sehari adalah 5 hidangan iaitu bersamaan dengan 400 gram yang terdiri daripada pelbagai jenis dan warna (NCCFN 2010). Pokok dan buah kurma banyak disebut di dalam al-Quran dan hadis nabi. Antara firman Allah S.W.T dalam surah al-Nahl 16:67 yang menerangkan bahawa pada buah tamar terdapat tanda kekuasaan Allah S.W.T.

Berdasarkan kajian yang telah dilakukan oleh Praveen (2012) mengenai tamar, ia menunjukkan bahawa kurma kaya dengan pigmen karotenoid. Karotenoid diperlukan tubuh badan manusia untuk melawan penyakit-penyakit kronik (Praveen 2012). Buah kurma kebiasaannya digunakan secara tradisi untuk masalah epilepsi, dehidrasi, masalah berkaitan jantung, ketidakseimbangan perut, pendarahan, jangkitan bakteria, demam dan keasidan perut (Yoganarasiman 2000). Hal ini membuktikan kurma adalah makanan sunnah yang sesuai untuk menjaga kesihatan perut dan pencernaan.

Buah Tin Buah tin atau buah ara dan saintifiknya ialah Ficus carica L. (Solomon et. al 2006). Allah S.W.T telah menyebut buah tin di dalam al-Quran di dalam surah yang dinamakan surah al-Tin 95:1. Menurut satu kajian didapati bahawa buah tin yang dikeringkan mengandungi serat yang sangat tinggi (Solomon et al. 2006). Berdasarkan kajian itu juga, buah tin dipetik secara rawak dan didapati mengandungi beberapa karotenoid seperti lutein, cryptoxanthin, lycopene, $\hat{a}$-carotene, dan $R$-carotene. Buah tin juga kaya dengan antioksida dengan jenis buah tin yang berwarna lebih gelap mempunyai kapasiti antioksida yang lebih tinggi berdasarkan jumlah polyphenols, flavonoids, dan anthocyanins yang lebih banyak. Antioksida bermanfaat dalam mengurangkan risiko penyakit yang merosakkan organ dan jaringan tubuh badan seperti kanser (Solomon et al. 2006).

Buah tin didapati mampu menghalang percambahan kanser perut tanpa sebarang kesan sitotoksik terhadap sel normal manusia (Hashemi et al. 2011). Pengambilan $5 \mathrm{mg} / \mathrm{mL}$ sehari merupakan pengambilan kepekatan optimum bagi menghalang pertumbuhan barisan sel kanser (Hashemi et al. 2011). Hal ini bertepatan dengan kadar tahunan bilangan pesakit kanser perut di Selatan Iran adalah rendah kerana berkaitan dengan amalan diet pengambilan buah tin sebagai rutin (Hashemi et al.2011).

Habbatus Sauda Habbatus sauda (Nigella sativa) atau dikenali sebagai 'black seed' memberi pelbagai manfaat dalam kesihatan (Kaskoos 2011). Dalam hadis juga ada disebutkan riwayat daripada Abu Hurairah yang bermaksud:
"Bahawa beliau mendengar Rasulullah s.a.w. bersabda, pada habbatus sauda itu ada penawar bagi setiap penyakit kecuali mati" (al-Bukhari 2001).

Jangkitan bakteria patogenik telah menjadi masalah kesihatan utama di seluruh dunia. Agen antimikrob yang baru amat diperlukan untuk mengatasi masalah ini. Menurut Hasan et al. (2013) ekstrak biji Nigella sativa (Habbatus sauda) didapati menjadi antibakteria terhadap beberapa strain bakteria patogenik (Streptococcus pyogene, Pseudomonas aeruginosa, Klebseilla pneumoniae dan Proteus vulgaris). Habbatus sauda dikenali sebagai rempah ratus dan digunakan dalam perubatan tradisi. Ia telah digunakan secara meluas sebagai anti hipertensi, tonik hati, diuretik, pencernaan, anti-cirit-birit, perangsang selera, analgesik, anti-bakteria dan gangguan kulit (Ahmad et al. 2013).

Air Al-Quran juga menyebut tentang kepentingan air dan funginya. Contohnya air sebagai minuman kepada manusia, haiwan dan tumbuhan (Surah al-Baqarah 2:164). Manakala Rasulullah pernah bersabda bahawa air zamzam dikatakan boleh menjadi penawar bergantung kepada tujuan ia diminum. Tekstur najis sangat dipengaruhi oleh kandungan air di dalam tubuh. Kadar serapan semula air daripada najis bergantung kepada tahap simpanan air di dalam badan. Garis panduan Diet Malaysia menyarankan individu dewasa supaya mengambil sekurang-kurangnya 8-10 gelas (2000-2500 mL) air sehari (NCCFN 2010).

Bijirin Menurut hadis sahih Al-Bukhari, Nabi Muhammad S.A.W. juga memakan tepung barli yang ditumbuk dan kulitnya diasingkan dengan hembusan. Bijirin seperti oat, barli dan beras perang mampu meningkatkan fungsi usus dengan melancarkan pergerakan peristalsis dengan meningkatkan berat jisim najis, memejalkan najis, menggalakkan pertumbuhan bakteria baik di dalam usus besar serta merencat pertumbuhan bakteria berbahaya (Spiller et al. 2003).

Senaman sebagai Pemangkin Diet yang Sihat Mengamalkan diet yang sihat sahaja adalah tidak lengkap tanpa bersenam. Kurang bersenam atau beraktiviti luar adalah antara punca sembelit, kanser usus besar, penyakit-penyakit kronik serta kemurungan (NCCFN 2010). Senaman mengurangkan sembelit dengan merangsang penguncupan otot usus. Otot usus yang kontrak dengan cekap membantu menggerakkan najis dengan cepat dan mengurangkan jumlah air yang diserap daripada najis ke dalam badan. Individu dewasa disarankan melakukan aktiviti fizikal berintensiti sederhana sekurang-kuranganya selama 150 min setiap minggu (WHO 2010). Contoh senaman intensiti sederhana adalah berjalan pantas, berbasikal, berenang dan bermain badminton yang boleh dilakukan sekurang-kurangnya 30 min setiap sesi sebanyak 5 kali seminggu. Dalam Islam, aktiviti fizikal adalah antara perkara penting yang ditekankan. Melakukan aktiviti riadah adalah antara amalan Rasulullah S.W.T. dan para sahabat seperti menunggang kuda, 
memanah dan berenang. Ini bertepatan dengan hadis Nabi Muhammad S.A.W yang diriwayatkan oleh al-Bayhaqi yang bermaksud:

"Didiklah anak-anak kamu memanah, renang dan menunggang kuda" (al-Bayhaqi Ahmad ibn Husayn. 1990. Sunan al-Kabir. Bairut: Dar al-Nawadir).

Oleh sebab itu, jika diperhatikan bahawa kebanyakan ibadah di dalam Islam memerlukan aktiviti fizikal seperti solat, sai', tawaf dan berjalan ke tempat ibadat (Ibn Qayyim 1990).

\section{KESIMPULAN}

Sistem pencernaan manusia yang rumit menghasilkan najis (tinja) yang merupakan bahan buangan manusia. Sifat najis manusia boleh dilihat melalui bentuk, warna dan bau najis disamping menentukan kesihatan manusia. Malah, dalam dunia yang serba moden ini, najis mempunyai pelbagai alternatif dalam memanfaatkan najis bagi menjamin kesihatan manusia dan pemeliharaan alam sekitar. Kajian ini juga mendapati najis manusia berbeza antara satu sama lain bergantung kepada diet, senaman, umur dan jantina. Daripada perspektif Islam, najis merujuk kepada sesuatu yang kotor malah Islam menekankan najis mesti dibersihkan sehingga hilang bau, warna dan rasa. Dalam menghubungkaitkan perspektif sains dan Islam, amalan diet makan-makanan sunnah telah membuktikan kebaikannya yang kaya dengan serat dan bernutrisi tinggi untuk diambil oleh manusia dalam memelihara kesihatan sistem pencernaan terutamanya. Malah, Islam juga menggalakkan aktiviti-aktiviti luar seperti bersenam, bersukan yang membantu kelancaran sistem penghadaman.

\section{PENGHARGAAN}

Pengarang mengucapkan terima kasih kepada kod projek penyelidikan FRGS/2/2013/SSI03/UKM/03/2, FRGS/2/2013/ SSI12/UKM/02/2, AP-2014-020 dan DPP-2015-FPI yang telah memberi sokongan sehingga terhasilnya penulisan ini.

\section{RUJUKAN}

Ahmad, A., Husain, A., Mujeeb, M., Khan, S.A., Najmi, A.K., Siddique, N.A., Damanhouri, Z.A. \& Anwar, F. 2013. A review on therapeutic potential of Nigella sativa: A miracle herb. Asian Pacific Journal of Tropical Biomedicine 3(5): 337-352.

Ahmad Ibn Hanbal, Abu Abdullah Ahmad bin Muhammad bin Hanbal. 2001. Musnad Ahmad bin Hanbal. Shuib Al-Arnaut, Adil Murshid \& Lain-lain (pnyt.). t.tp: Muassasah al-Risalah. Al-Bukhari, Muhammad bin Ismail. 2001. Sahih Al-Bukhari. Muhammad Zahir bin Nasir Al-Nasir (pnyt.). t.tp: Dar Taq al-Najah

Al-Quran. Surah al-Tin 95: 1.

Al-Quran. Surah al-Nahl 16: 67.

Al-Quran. Surah al-Baqarah 2: 164.
Al-Tabarani, Abu Al-Qasim Sulaiman bin Ahmad bin Ayub. 1994. Al-Mujam Al-Kabir. Hamdi bin Abd Al-Majid Al-Salafi (pnyt.). Ed. Ke 2. Al-Qaherah: Maktabah Ibn Taimiyah.

Al-Sharbini, Muhammad ibn Muhammad. 1994. Mugni Al-Muhtaj. Qaherah: Al-Maktabah Al-Tawfiqiyyah. 1: 149.

Ariff, M.I. 2013. Prinsip penentuan hukum makanan ubah suai genatik yang berasaskan haiwan. Tesis Ph.D. Jabatan Syariah, Fakulti Pengajian Islam, Universiti Kebangsaan Malaysia, Bangi (tidak diterbitkan).

Arseculeratne, S.N., Gunatilaka, A.A.L. \& Panabokke, R.G. 1985. Studies on medicinal plants of Sri Lanka. Part 14. Toxicity of some traditional medicinal herbs. Journal of Ethnopharmacology 13: 323-335.

Bai,F. \& Wang, X. 2011. Study on dynamics model of biodegration of organic matter in aerobic mesophilic composting reactor for sanitary disposal of human feces. International Conference on Environmental, Biomedical and Biotechnology Shanghai. Singapore: IACSIT Press. hlm. 11-16.

Caroline, B.R. \& Mary, T.K. 2008. Textbook of Basic Nursing. 9th ed. Philadelphia: Walters Kluwer. Lippincott Williams \& Wilkins.

Choong, C.H.,Peter,L.C.C. \& Tan, K.L.2017. Science: PT3. Shah Alam: Oxford Fajar Sdn. Bhd.

Corsetti, M., De Nardi, P., Di Pietro, S., Passaretti, S., Testoni, P.A. \& Staudacher, C. 2009. Rectal distensibility and symptoms after stapled and Milligan-Morgan operation for hemorrhoids. Journal of Gastrointestinal Surgery 13(12): 2245-2251.

Davies, G., Crowder, M., Reid, B. \& Dickerson, J. 1986. Bowel function measurements of individuals with different eating patterns. Gut 27(2): 164-169.

Dnews. 2015. Will the future be powered by feces. https://www. seeker.com/will-the-future-be-powered-by-feces-1770422570. html. Diakses pada 15 April 2017.

Edward, G. 2007. Complete Colon Cleanse: The at Home Detox Program to Restore Good Health, Boost Vitality and Ensure Longevity. United States: Ulysses Press.

Faszly, R., Nasyrudin, W.A. \& Aminah, A. 2015. Indahnya Pemakanan dan Perubatan Islam: Keajaiban Penyembuhan dengan Farmakologi Alam. Kuala Lumpur: Telaga Biru Sdn. Bhd.

Frederika, W. 2014. Poo power: Turning human waste into clean energy in Kenya's slums. https://www.theguardian.com/ global-development-professionals-network/2014/oct/15/ poo-power-renewable-energy-kenya-slums-biogas. Diakses pada 12 April 2017.

Guyton, A.C. \& Hall, J. 2000. Textbook of Medical Physiology. 12th ed. Philadelphia.: WB Saunders.

Hannah, M.W. 2007. Bacteroides: The good, the bad, and the nitty-gritty. Clinical Microbiology Review 20(4): 593-621.

Hasan, N.A., Nawahwi, M.Z.\& Ab Malek, H. 2013. Antimicrobial activity of Nigella sativa seed extract. Sains Malaysiana 42(2): 143-147.

Hashemi, S.A., Abediankenari, S., Ghasemi, M., Azadbakht, M., Yousefzadeh, Y. \& Dehpour, A.A. 2011. The effect of fig tree latex (Ficus carica) on stomach cancer line. Iranian Red Crescent Medical Journal 13(4): 272.

Heaton, K.R.J., Cripps, H., Mountford, R., Braddon, F. \& Hughes, A. 1992. Defecation frequency and timing, and stool form in the general population: A prospective study. Gut 33(6): 818-824.

Ibn Majah, Muhammad ibn Yazid. 1999. Sunan Ibn Majah. Damascus, Syiria: Dar al-Bashair. No. Hadis: 1127. 
Ibn Qayyim, Muhammad bin Abi Bakr bin Ayub. 1990. Tafsir AlQuran Al-Karim. Sheikh Ibrahim Ramadan (pnyt.). Beirut: Maktabah al-Hilal.

Ismet, B. \& Cumhur, A. 2014. Investigating some microbial pollution parameters of seawater and mussels (Mytilusgallo provincialis, Lamarck 1819) of Sinopblack sea coastal zone, Turkey. Sain Malaysiana 43(12): 1835-1842.

Kantor, L.S., Variyam, J.N., Allshouse, J.E., Putnam, J.J. \& Lin, B.H. 2001. Choose a variety of grains daily, especially whole grains: A challenge for consumers. The Journal of Nutrition 131(2): 473-486.

Kaskoos, R.A. 2011. Fatty acid composition of black cumin oil from Iraq. Research Journal of Medicinal Plant 5(1): 85-89.

Lei, F., Zhang, X.N., Wang, W., Xing, D.M., Xie, W.D., Su, H. \& Du, L.J. 2007. Evidence of anti-obesity effects of the pomegranate leaf extract in high-fat diet induced obese mice. International Journal of Obesity 31(6): 1023-1029.

Magee, E.A., Richardson, C.J., Hughes, R. \& Cummings, J.H. 2000. Contribution of dietary protein to sulfide production in the large intestine: An in vitro and a controlled feeding study in humans. The American Journal of Clinical Nutrition 72(6): 1488-1494.

National Coordinating Committee on Food and Nutrition (NCCFN). 2010. Malaysian Dietary Guidelines. Kuala Lumpur: Ministry of Health Malaysia.

Panth, N., Manandhar, B. \& Paudel, K.R. 2017. Anticancer activity of Punica granatum (pomegranate): A review. Phytotherapy Research 31(4): 568-578.

Patricia, A.,Potter, A.G.P. \& Patricia, S.A.H. 2015. Essentials for Nursing Practice. St. Louis: Missouri: Elsevier Inc.

Paudel, G., Rai, L., Saud, B.\& Dhungana, G. 2017. Prevalence of intestinal parasitic infection among rural area school children of Lokhim VDC Nepal. J. Microbiology \& Experimentation 4(1): 102.

Praveen, K.V. 2012. Date fruits (Phoenix dactylifera Linn). An Emerging Medicinal Food, Critical Reviews in Food Science and Nutrition 52(3): 249-271.

Ramirez, V.R., Mostacero, L.J., Garcia, A.E., Mejia, C.F., Pelaez, P.F., Medina, C.D. \& Miranda, C.H. 1988. Vegetales Empleados en Medicina Tradicional Norperuana. Banco Agrariodel Peru and University of Trujillo, Trujilla, Peru. p. 54.

Rose, C., Parker, A., Jefferson, B. \& Cartmell, E. 2015. The characterization of feces and urine: A review of the literature to inform advanced treatment technology. Critical Reviews in Environmental Science and Technology 45(17): 1827-1879.

Rowan, K. 2012. Poop Transplants' May Combat Bacterial Infections. LiveScience.com. Diakses pada 14 April 2017.

Silvester, K.R., Bingham, S.A., Pollock, J.R.A., Cummings, J.H. \& O'Neill, I.K. 1997. Effect of meat and resistant starch on fecal excretion of apparent N-nitroso compounds and ammonia from the human large bowel. Nutrition and Cancer 29(1): 13-23.

Solomon, A., Golubowicz, A., Yablowicz, Z., Grossman, S., Gottlieb, H., Altman, A., Kerem, Z. \& Flaishman, A. 2006. Antioxidant activities and anthocyanin content of fresh fruits of common fig (Ficus carica L.). Journal Agriculture Food Chemistry 54: 7717-7723.

Spiller, G.A., Story, J.A., Furumoto, E.J., Chezem, J.C. \& Spiller, M. 2003. Effect of tartaric acid and dietary fibre from sundried raisins on colonic function and on bile acid and volatile fatty acid excretion in healthy adults. British Journal of Nutrition 90(4): 803-807.
Süntar, I.P., Akkol, E.K. \& Baykal, T. 2010. Assessment of antiinflammatory and antinociceptive activities of Olea europaea L. Journal of Medicine Food 13(2): 352-356.

Volk, T. \& Rummel, J.D. 1987. Mass balances for a biological life support system simulation model. Advances in Space Research 7(4): 141-148.

Wierdsma, J., van Zuilen, A. \& van der Bijl, J. 2011. Self-efficacy and long-term medication use in patients with chronic kidney disease. Journal of Renal Care 37(3): 158-166.

World Health Organization. 2010. Global Recommendations on Physical Activity for Health. Geneva, Switzerland: World Health Organization.

Yoganarasiman, S.N. 2000. Medicinal Plants of India-Tamilnadu. Vol II. Bangalore: International Book Publisher Cyper media. hlm. 48-62.

Mohd Izhar Ariff Mohd Kashim* Jabatan Syariah, Fakulti Pengajian Islam

Universiti Kebangsaan Malaysia 43600 UKM Bangi, Selangor Darul Ehsan Malaysia

Nur Asmadayana Hasim, Muhammad Adib Samsudin, Mohammad Zaini Yahaya \& Latifah Amin Institut Islam Hadhari, Fakulti Pengajian Islam

Universiti Kebangsaan Malaysia 43600 UKM Bangi, Selangor Darul Ehsan Malaysia

Rizafizah Othaman \& Rozida Khalid

Pusat Pengajian Sains Kimia dan Teknologi Makanan

Fakulti Sains dan Teknologi

Universiti Kebangsaan Malaysia

43600 UKM Bangi, Selangor Darul Ehsan

Malaysia

Nur Asmadayana Hasim \& Latifah Amin

Pusat Citra Universiti

Universiti Kebangsaan Malaysia

43600 UKM Bangi, Selangor Darul Ehsan

Malaysia

Zahara Abdul Manaf

Pusat Sains Jagaan Kesihatan

Fakulti Sains Kesihatan

Universiti Kebangsaan Malaysia

Jalan Raja Muda Abdul Aziz

50300 Kuala Lumpur, Wilayah Persekutuan

Malaysia

Diani Mardiana Mat Zin

Kolej Permata Insan

Universiti Sains Islam Malaysia

Bandar Baru Nilai

71800, Nilai, Negeri Sembilan

Malaysia

*Pengarang untuk surat-menyurat; email: izhar@ukm.edu.my

Diserahkan: 27 Julai 2017

Diterima: 5 Februari 2018 